\title{
Educational Leaders As Change Agents Towards the Information Literate School
}

\author{
Maria Noemi M. MONCADA \\ Public Secondary School Principal \\ Department of Education Philippines
}

\begin{abstract}
Over the last decade, the development of new information and communication Technologies (ICT) has provided a variety of opportunities for people all over the world. But still, the vast majority of society remains untouched by the digital revolution, creating real disparities between and within countries and socioeconomic groups. Undoubtedly, ICT plays a vital role in the future of our societies especially in Education. School heads, decision makers, local authorities and school librarians have significant role to play in the development of information literacy in schools. School principals trained in ICT should initiate information literacy in their schools and should provide support to secure cooperative deals and development aid. In the Philippine Educational System, schools located in affluent cities especially those schools in the capital are fully equipped with information infrastructure but too many schools in secondary cities and remote provinces are deprived of the tools to access information.
\end{abstract}

\section{Overview}

Information Literacy (IL) forms the basis for lifelong learning. It is common to all disciplines, to all learning environments and to all labels of education. Developing lifelong learners must be the central mission of all educational institutions, ensuring that individuals have the intellectual abilities of reasoning and critical thinking and helping them construct a framework for learning how to learn. In incorporating information literacy access curricula in all school programs and services requires the collaborative efforts of school principals, teachers and librarians.

School heads should become information technology leaders in their school communities through lectures and by leading discussion, training, symposia, benchmarking and networking. Teachers should inspire students to explore the unknown, offer guidance on how best to fulfill information needs and monitor their progress. Librarians should coordinate the evaluation and seek intellectual resources for programs and services, organize and maintain collections and to provide instruction to students, faculty and the community who seek information.

School Principals should create opportunities for collaboration and staff development among faculty, librarians, other professionals, non-governmental organizations, local government units and members of the community who initiate information literacy programs. They should plan programs and provide ongoing resources to sustain them.

Technology has the potential to open classrooms to a greater world of learning experiences leading to information literacy. Educators are now challenged to prepare their students for a technology-driven environment and to identify the impact of ICT in the school information literacy program. The difference between a 
classroom full of computers and a classroom full of learners is how the teacher utilizes technology as a tool. The "teaching with technology", by information literacy integration will allow teachers to fully utilize the collaborative environment of a connected learning community.

In the Philippines, the initiative emphasizes ICT proficiency, work force development and community development. The "teaching technology" curricula focus on desktop efficiency, technical support, basic networking and application development. This enables the school to empower their teachers and students with lifelong skills.

\section{Successful school leadership}

In this period of heightened concern for student learning, school leaders are being held accountable for how well teachers teach and how much students learn. They must respond to a complex environment and serve all students well. This complex environment requires a paradigm shift, that is transformation of a traditional school into an information literate school to cope with contemporary and future needs - information literacy as a prerequisite for lifelong learning. Information Literacy is the ability "to recognize when information is needed and the ability to locate, evaluate and use effectively the needed information." How can we reach information literacy for lifelong learning? Leadership must play a great role.

Scratch the surface of an excellent school and you are likely to find an excellent principal. Peer into a failing school and you will find weak leadership. Leaders are thought to be essential for high-quality education. Principals must respond to increasing diversity in student characteristics, including socio-cultural background, income disparities, physical and mental disabilities and variation in learning capacities. They must manage new collaborations with other professionals, non-governmental organizations, local government units and other members of the community that serve children whose focus is information literacy.

\section{What is leadership?}

Leaders mobilize and work with others to achieve shared goals. This definition has the following implications:

- Leaders do not merely impose goals on followers but work with others to create a shared sense of purpose and direction. In public education, the ends are increasingly centered on student learning, including both the development of academic knowledge and skill and the learning of important values and disposition.

- Leaders primarily work through and with other people. School leaders therefore, are people occupying various roles in the school who provide direction and exert influence in others to achieve the school's goals. 
In building collaborative processes, educational leaders enhance the performance of their schools by providing opportunities for staff to participate in decision making about issues that affect them and for which their knowledge is crucial. In this way, leaders help others to shape the school in ways that accomplish shared goals and address individual concerns as well.

In managing the environment, effective leaders work with representatives from the school's environment, including parents, community members, business and government liaisons and other influential leaders. They pursue positive interactions with the goals of fostering shared meanings, garnering resources and support, and establishing productive inter-organizational relationships. To effectively position schools within their environments, and to respond to legitimate concerns from parents and others, educational leaders are client-centered, proactive and focused. "A successful leader needs to do more but cannot do less.”

\section{Classical leadership}

Leadership seems to be one of those qualities that you recognise when you see it, but is difficult to describe. Many, associate leadership with one person leading. Four things stand out in this respect as pointed out by Gardner (1989).

- $\quad$ To lead involves influencing others.

- Where there are leaders there are followers.

- Leaders seem to come to the fore when there is a crisis or special problem. They often become visible when an innovative response is needed.

- Leaders are people who have a clear idea of what they want to achieve and why.

Thus, leaders are people who are able to think and act creatively in nonroutine situations - and who set out to influence the actions, beliefs and feelings of others. Not all managers are leaders; and not all leaders are managers.

Attributes of school principals, decision makers and school librarians, in promoting information literacy in schools.

In Gardner's (1989) leadership attributes, he enumerated the following qualities or attributes of a leader that are applicable to the desired attributes of school principals, decision makers and school librarians in promoting information literacy in schools.

- Physical vitality and stamina

- Intelligence and action-oriented judgment

- Eagerness to accept responsibility

- Task competence

- Understanding of followers and their needs

- Skill in dealing with people

- Need for achievement

- Capacity to motivate people 
- Courage and resolution

- Trustworthiness

- Decisiveness

- Self-confidence

- Assertiveness

- Adaptability

- Flexibility

others.”

"If leaders are liked and respected, they are more likely to have support of

\section{Leadership for learning: Transforming a traditional school into an information literate school}

\section{Autonomy and isolation}

Educators are isolated from the fast-changing world of globalization and business innovation. Most do not understand the fundamental changes that have taken place in the world of work, changes that require that, to be successful, students will have to have very different skills from those needed by an earlier generation. Lacking daily exposure in their own workplace to these fundamental economic changes, most educators do not understand the urgency of many business and political leaders.

Educators who spend most of their workday with children are also largely isolated from contact with other adults. (Wagner 2004). The problems and challenges in the $21^{\text {st }}$ Century workplace are impossible to be solved alone.

\section{The role of benchmarking in leadership}

Benchmarking or "best practice benchmarking" is a process by managemers to evaluate various aspects of their business processes in relation to best practice, usually within their own industry. This then allows organisations to develop plans to adopt such practices. This process can help leaders achieve their visions and missions in education towards lifelong learning through information literacy.

Effective leaders give teams of experienced teachers - the building teachers, time to visit successful schools and communicate what they have learned with colleagues. Teachers need to see models of more successful classrooms and programs in order to believe that all students and all school programs can succeed. Benchmarking may be treated as a one-off event, but should be treated as a continuous process in which schools continually seek to challenge their practices. Simple procedures in benchmarking for our schools (Camp, 1989):

- Identify problem areas

- Identify organizations, institutions or schools that are leaders in these areas 
- Study their best practices. An initial study can be done at a good school library or online

- Implement the best practices

- Repeat. Benchmarking is an ongoing process. Best practices can always be made better.

\section{Role of Networking}

Webster defined networking as the exchange of information or services among individuals, groups or institutions. In information technology, a network consists of two or more connected computers that communicate with each other. Like the Internet, education leaders must learn to network information or services to help them achieve their goals and informational aspirations. In the networking age, all can be creators and creation involves working in, not just watching digital media.

It is important to recognize that progress is accelerating. Change is not something that can easily be witnessed in the short term, especially when we are conditioned to be passive consumers and entrenched in tradition. We are, in fact, reconciling and consolidating new knowledge from formerly disparate and isolated areas in a self-reinforcing cycle of breakthrough and discovery.

\section{Understanding the imperative for change}

Why is change needed in schools? Wagner (2004) suggests that our system of education was designed to serve as a sorting machine. Historically, we sorted out the 20 percent of students who were going on to college and to professional and managerial careers and gave them skills they needed. The rest received the functional equivalent of an eight-grade education - the minimum needed for work and citizenship for most of the $20^{\text {th }}$ century.

Now, all students need different and more sophisticated skills, such as the ability to solve problems, work in teams, and learn independently. Students who leave high school with a diploma and no skills or plans for further learning are, in effect, being sentenced to a lifetime of subsistence wages and marginal employment. This creates the challenge of educating all students to higher standards and equipping them for a future of lifelong learning.

Henri (1995) interpreted lifelong learning as engaging people with learning throughout all stages of their lives. Lifelong learning at secondary school level is concerned with keeping students engaged in learning and developing in those students the characteristics that will make learning an integral part of their lives when they leave school. School leaders shall play a vital role for change in schools with a focus on information literacy, a prerequisite for lifelong learning environment and for all levels of educational attainment.

Leaders must themselves clearly understand the need for change and then create a framework and forums for discussion. Everyone in the community needs to understand the ways in which our society has changed and the implications for education and parenting. Leaders must make the challenge "blame-free" and the solution a shared responsibility. They must make it clear that the issues faced in 
schools are not the fault of teachers, parents and students to blame. Lastly, leaders need to create time for educators to understand and discuss different kinds of data.

For many leaders, a shared vision begins and ends with a school mission. More is needed to transform schools - a different kind of engagement on the part of students, teachers, parents and the community, and a new understanding of the leadership qualities that nurture such engagement. The biggest challenge for educational leaders is to nurture such engagement and commitment in the community. To create such learning communities requires both new structures and a very different spirit.

\section{Mapping the Information Literate School Community}

Henri (1995) articulated a tentative set of benchmarks that could be used to assess a schools’ progress towards an information literacy culture.

Whole School Focus

- The school has a set of information policies in place

- The school has adopted an information technology plan

- The school has an Internet portal. Learning is the dominant consideration in its design and maintenance

- The school has benchmarked information competencies that are expected of students at key points in their school career

- Information skills are taught/learned across the curriculum and in the context of authentic content learning

- The process of learning from information - of constructing knowledge - is always the focus of teaching and learning

Principal Focus

- $\quad$ The principal demonstrates information leadership

- $\quad$ The principal fosters knowledge management, requires timely information for corporate decision-making, and provides the resources to make this possible

- Information leaders (ICT coordinator, teacher librarian) are members of the key curriculum committee

Teacher Focus

- $\quad$ The school supports the professional development of staff with respect to information literacy 
- $\quad$ Teachers demonstrate that they are excellent learners

- $\quad$ Teachers talk, dream, plan and teach as a team rather than as a group of individuals

- $\quad$ Teachers seek evidence that students are constructing their own meaning

Teacher Librarian Focus

- A significant percentage of school funds are budgeted for the provision of information services

- $\quad$ The school understands and defends the role of the teacher librarian, as articulated in policy documents

- $\quad$ The school requires that the teacher in-charge of information services be a qualified teacher librarian

\section{Student Focus}

- $\quad$ The school requires students to build electronic portfolios as evidence of their level of information literacy

- The school monitors the information work demands that are placed on each student. Careful scrutiny is applied before students are requested to locate information outside school

- $\quad$ Reporting on student achievement focuses on how the student is maturing as a learner

- $\quad$ Teachers encourage student collaboration in many aspects of their learning

- Learning contexts are varied and involve students in the meaningful use of a wide range of information resources.

- When students are required to undertake homework that involves a step(s) in the information process, teachers consider issues of social justice, equity, and the domestic demands placed on students

- $\quad$ Students are encouraged to provide constructive feedback to teachers with respect to information based learning tasks

- $\quad$ Students maintain logs or other records of their learning - the successes and challenges - and are involved in self-assessment

Schools that are serious about substantive change and adopting a "learning to learn” paradigm are encouraged to construct and mold information literate communities where teachers are themselves information literate. This shift in thinking brings with it many shifts in practice and has special implications for the role of teacher librarian and the purpose of information services in schools.

A teacher librarian may act as a catalyst for change by:

Policy development

- $\quad$ Encouraging discussion about the effects an information policy might have on teaching and learning

- $\quad$ Encouraging the involvement of all staff in the formulation of an information policy, considering how much a policy might affect them and their teaching programs 
- $\quad$ Advocating that the library is a duty area and that all staff should be scheduled there throughout the year

- Involvement in the development/revision of homework policy/practice.

- $\quad$ Participating in lobby groups such as in support of the development of union policies on working conditions, responsibilities, rights, etc.

Information services

- Mapping the information resources in the school so that these can be matched against curriculum requirements

- Using program budgeting to ensure that adequate funding is allocated to support resource based learning and the provision of information services

- Identifying skills based learning goals from curriculum documents and developing levels of performance indicators for the identification of information literacy

- Ensuring that the school is up-to-date about current information services/sources and the ways that these can be used to support/resource of the curriculum

- Encouraging teachers to call upon teacher librarian expertise

- Seeking funding from outside school sources to support school based information literacy initiatives

- Ensuring maximum usage of the library through extended opening and eventually through electronic access

- Disseminating professional reading to colleagues

Learning Assessment

- Providing a significant contribution to the development of a whole school information literacy programs

- Encouraging the use of assessment techniques that demonstrate the acquisition of information-based competencies

- Modeling lifelong learning by testing information skills/ strategies

- Collaborating with teachers to integrate information skills/strategies into teaching programs

- Fighting vigorously for an unscheduled library timetable and maintaining an open door policy for information seekers

- Reinforcing the desirability of student self-assessment and the use of meta-cognitive tools (thinking/learning logs etc.)

Integration of ICT

- Ensure that the school is aware of the educational potential of available information technologies and that information technology needs are prioritized with the allocation of appropriate funding

- Argue for the integration of information technology into all teaching programs

Continuing professional development

- Ensuring that teachers are efficient library users 
- Providing teachers with strategies to implement/integrate information skills/strategies into their teaching programs

\section{Case study : Juan Sumulong High School, Quezon City, Philippines}

Juan Sumulong High School is a public secondary school in the Philippines which draws students from underprivileged communities within its catchments area. The school's mission is to provide access to quality education in order to produce morally upright, healthy, self reliant, productive, peace loving citizens who are responsive to the needs of the community and the country towards lifelong learning through Information Literacy Program.

Juan Sumulong High School envisions a teaching environment where:

- Teachers are information literate and are able to achieve learning outcomes not only because they are empowered, competent and accountable, but because they are committed

- Students are highly motivated, ICT literate, and serious in their academic work in preparation for their entry into higher institutions and a career with lifelong learning

- Physical facilities are upgraded and enhanced to make the school environment conducive to learning and globally competitive

- The family, the community, and other professionals and institutions actively support the attainment of school objectives

Aware of the students' need to be globally competitive, the Principal established the school's first computer lab equipped with 25 new computers, a printer, a multimedia projector, a scanner, 21-inch colored TV, an electronic microscope, CDROM, web camera, pointers, CD-writer and Internet connection. No government fund was utilized. The Principal personally requested owners of reputable computer schools in the Philippines like the STI, AMA Computer College and Massachusetts Computer School in the Philippines to provide a scholarship program in basic computer education to at least 50 percent of the 105 teachers in school year 20002001. The remainder was trained by two of the best computer education teachers utilizing the school's computer lab.

To encourage computer and information literacy, basic computer and information education for interested students in the third year, and fourth year level training was offered as an elective/optional subject in Technology and Livelihood Education, a non-academic subject in the Philippines. Later, in school year 2002 up to the present, basic computer education is offered for all year levels.

It is sad to note that some school libraries including that of Juan Sumulong High School are only able to provide limited resources. However, as ICT develops, the school realised the importance of upgrading its library to suit the needs of students, 
teachers, researchers and the community. Improvements have included computers, Internet access, scanner, printer, CD-ROMs, interactive encyclopedia and OPAC.

Cognizant of the need to provide the students with updated reference materials and books in order to keep them globally competitive, Juan Sumulong High School started to innovate and adopt a modern system of research in year 2001. In 2000 the Principal visited Seattle Central Community College (USA) and was impressed by its electronic library (e-library).

Upon her return to the Philippines, she discussed the e-library with the school librarian. The librarian had developed a modified approach in classification, based on DDC, which was initially used in the school library's organization of collections. The application of color-coding for mnemonic purposes was also introduced. The Principal had consulted various organizations, seeking support for the plan to convert the school's library into an e-library. Her efforts started to bear fruit when donations were received of computer tables and chairs, books, scholarship certificates, air conditioning units, refurbished computers, and financial support for their maintenance. Free consultation for the formal organization of the school's electronic library was provided by the Director of Rizal Library in Ateneo de Manila University. Non-governmental organizations, Christian organizations, parent-teacher and community organizations, contractors and personal friends of the Principal responded to the needs of the electronic library.

With the support of the Schools Division Superintendent within the Department of Education, the proposal for transforming the traditional library into an electronic library was presented and approved by the Mayor of Quezon City, the Honorable Feliciano R. Belmonte, Jr. The refurbished computers were replaced by ten flat screen Pentium IV computers, CD-writer, printers and a centralized electronic library system (SB PhpMyLibrary) developed using open source software exclusively licensed to Juan Sumulong High School's e-library. They were provided by the City Mayor who also paid the Internet subscription for the e-library.

After the launch of this first electronic school library in Quezon City, in September 16, 2003, the school was declared a field trip site in the National Capital Region comprising thirteen cities in Metro Manila, by the Director of the Department of Education in 2003. It was used as venue for computer training of other institutions which has become a financial source for its maintenance. Ten other school e-libraries have now opened in Quezon City, and there are more in other cities in Metropolitan Manila. Awareness that Juan Sumulong is fully equipped with staff who are computer and information literate, students trained for lifelong learning, and fully equipped with facilities required in an information literate school, foreign educators and students regularly visit and observe classes integrating ICT and IL.

The objective of the Principal in establishing the electronic library is to provide students and teachers easy access to current, up-to-date and unlimited sources of information through the use of an appropriate integrated library information system, internet facilities and CD-ROM bibliographic and full-text database. With the elibrary, cataloguing and classifying reference materials have become easy tasks. It has facilitated fast access to information found on the website of the Library of Congress. 
Because of the Principal's educational leadership, the Juan Sumulong High School, was chosen to be the Pilot School, assigning her as the pilot principal in an international project participated by eight ASEAN countries sponsored by the Department of Education and UNESCO a three-year program funded by the Japan Funds in Trust entitled "School NET PILOT Project". Its whose mission is to strengthen ICT use in schools and School Net in the ASEAN setting. Participating countries are Indonesia, Malaysia, Thailand, Cambodia, Laos PDR, Myanmar, Vietnam and the Philippines. The "teaching with technology" ICT integration framework will allow teachers to fully utilize the collaborative environment of a connected learning community. The school has been featured in InfoNet Magazine in 2004 titled "JSHS E-Library, keeping at PAR with Technology." Also, IFLA and UNESCO accepted a paper written by the school librarian, titled "Juan Sumulong High School Electronic Library in the Division of Quezon City, Philippines.”

The school has established its second School Net Computer Lab with personalized computer tables to accommodate thirty-three computers donated by the Busan Ministry of Education (South Korea), fully equipped with air-conditioning units, multimedia projector, sound system, scanner, printer and CD-ROMs which will be used by the pilot class in teaching and learning Science, English and Mathematics under the School Net Pilot Project of UNESCO. These facilities and innovations came into reality due to leadership, benchmarking, networking and shared vision of the school populace, community, other professionals, non-governmental organizations, local government units, the department of education, parents and the teachers.

Because of leadership in education, Juan Sumulong High School is now an ICT-information literate school, a Pilot School for ICT-L Programs, is globally competitive, where teachers are utilized as international consultants, trainers, facilitators, educational writers and pilot teachers. Leadership in education is moving students in Juan Sumulong High School in Quezon City, Philippines towards lifelong learning. It is envisioned that through quality education, Juan Sumulong High School will continue to be an active and dynamic member of the community in bringing about an enlightened, productive and morally strong citizenry in order to achieve richer and fuller lives in the service of God and country.

\section{References}

Gardner, J., (1989). On leadership. Available at http://www.education.yahoo.com/reference/encyclopedia/entry/entry?id=18420. (viewed on 19 April 1995)

Henri, J. (1995). Mapping the information literate school community. Paper presented during the IFLAALP Workshop entitled "Building Learning Communities through Libraries Workshop I" held at the Ateneo de Manila University-Rizal Library, Philippines on 13-14 April 2005

Herrera, M., (2004). "Moving on to an information society” InfoNet Magazine, 12 (1), 19.

Information literacy. Available at http://www.wikipedia.org/wiki/Information_literacy (viewed on 19 April 2005)

Leithwood, K. \& C. Riehl, (2003). What we know about successful school leadership. Philadelphia, PA: Laboratory for Student Success, Temple University. Available at www.cepa.gse.rutgers.edu/whatweknow.pdf. (viewed on 19 April 2005)

Wagner, T, (2004). Leadership for learning: An action theory of school change. Available at http://www.pdkint.org/kappan/k0101wag.htm. (viewed on 19 April 2005) 


\section{Author note}

Dr. Maria Noemi M. Moncada is an innovator-implementor of the first public secondary school e-library in Quezon City, Philippines and Principal-leader of the School Net Pilot Program of DepED Philippines and UNESCO. She earned her Doctor of Education in Administration and Supervision and also has a Bachelor of Law. She is a member of Congress of Southeast Asian Librarians (CONSAL), International Association of School Librarianship (IASL) and Filipino American Educators Foundation. 
Reproduced with permission of the copyright owner. Further reproduction prohibited without permission. 